\title{
Correlation Analysis of Impact of Natural Parameters on Water Quality of the River Danube Near Novi Sad for the Period 2004-2011
}

\author{
Pantelić MilanaA*, Dolinaj Dragan ${ }^{A}$, Stankov Uglješa ${ }^{B}$, Leščešen Igor ${ }^{B}$ \\ Received: September 2013 | Revised: September 2013 | Accepted: September 2013
}

\begin{abstract}
The river Danube belongs to the Black Sea basin and it flows through ten European countries. It also flows through 35 larger cities including Novi Sad in Serbia. The water quality of the Danube is one of significant factors that are taken into consideration in evaluation of sustainability of the development of this region and it is controlled by complex anthropogenic activities and natural factors. With the assistance of correlation analysis, the paper studied the impact of natural factors such as water temperature, air temperature and precipitation rate on certain parameters indicating the water quality. Based on the results of the study it has been determined that natural factors affect changes in water quality throughout the year and that water temperature affects most the concentration of nitrogen oxide.
\end{abstract}

Key words: natural factors, water quality, correlation, the Danube, Serbia

\section{Introduction}

Preservation and rational use of water resources, which are considered the most important segment of the environment and foundation of sustainable development, represents one of the most important issues in the $21^{\text {st }}$ century. Water as the resource is valued by quantity, quality, and status, whereby the quality implies the condition of the aquatic system expressed via physical-chemical, chemical, and biological indicators. In many settlements, rivers and river canals are the main sources of water for industry, agriculture, and water supply of households. Water quality is one of the most significant factors that have to be taken into account in evaluation of sustainability of a particular region (Córdoba et al., 2010). Significant aspects that are taken into the account in assessment of priority issues relating to water quality include the economic effects, impact on human health, impact on the eco-system, impact of a geographic area and temporal duration of an impact (Dalmacija, 2004). Surface water quality is governed by complex anthropogenic activities and natural factors (Bhaduri et al., 2001; Ren et al., 2003; Xian et al., 2007), and it depends on several main effects: basin lithology, atmospheric impacts, climate conditions and anthropogenic effects (Shrestha, Kazama, 2007).

Temperature is one of the factors that may affect the water quality. The increase of water temperature results with the increased biological activity and reduced dissolved oxygen concentration (Sa'nchez, 2007). Due to this, the water quality is usually poorer during the warmer period of the year, namely during spring and summer compared to autumn and winter. Many researchers have confirmed such a trend (Bordalo et al., 2001; Rudolf et al., 2002; Herna'ndezRomero et al., 2004).

A Climatology and Hydrology Research Centre, Faculty of Science, University of Novi Sad; Trg Dositeja Obradovića 3, 21000 Novi Sad, Serbia

B Faculty of Sciences, Department of Geography, Tourism and Hotel Management, University of Novi Sad, Trg Dositeja Obradovića 3, 21000 Novi Sad, Serbia

* Corresponding author: Milana Pantelić, e-mail: milana.pasic@dgt.uns.ac.rs 
In this paper, we studied the effects of natural factors on water quality of the river Danube near Novi Sad. The objective of the paper is to establish the impact of natural factors such as water temperature, air temperature and precipitation rate on certain parameters indicating the water quality based on a particular statistical method.

\section{Main characteristics of the studied area}

The river Danube belongs to the Black Sea basin and it is the second largest river in Europe after Volga. The river Danube, which is known to us as a large and powerful river, disposes with the average flow of only $7,27 \mathrm{~m}^{3} / \mathrm{s}$ in the initial sections of its flow and it provides the Black Sea with $6550 \mathrm{~m}^{3} / \mathrm{s}$ of water on the average. The Danube is $2,783.4 \mathrm{~km}$ long and the surface of its basin covers $817,000 \mathrm{~km}^{2}$ (Gavrilović, Dukić, 2002). The Danube is the only large European river that flows from the west to the east and it flows through Germany, Austria, Slovakia, Hungary, Croatia, Serbia, Romania, Bulgaria, Moldova, and Ukraine. There are 115 million inhabitants in these countries and they belong to 18 different nations. The Danube flows through 35 large cities, including Novi Sad in Serbia. The Dan- ube receives water from the territories of 17 countries and it is considered "the most international" river in the world.

When it comes to the Danube section that flows through Serbia, it starts at Bezdan and flows to Prahovo. The Danube flow through Serbia is $588 \mathrm{~km}$ long - $137.6 \mathrm{~km}$ are the shared sector with Croatia and 299.35 $\mathrm{km}$ with Romania. The river is navigable along the entire length through Serbia. As the most important European river course, the Danube provides possibilities for further economic development in Europe. International tourist cruises along the Corridor VII affect also the affirmation of the Danube region in Serbia, in particular of certain sites of tourist value. The areas that have suffered the economic stagnation within the last decades are being revived in such a way (Milanović, 2010). Serbia is the largest polluter of the Danube compared to other European countries. Our country does not have a developed wastewater treatment system and that is why all waste from the sewer is discharged directly into the Danube. Factories do not have necessary filters and agricultural holdings also discharge their waste into the river. Rehabilitation projects are very expensive and the state is not dealing with this problem.

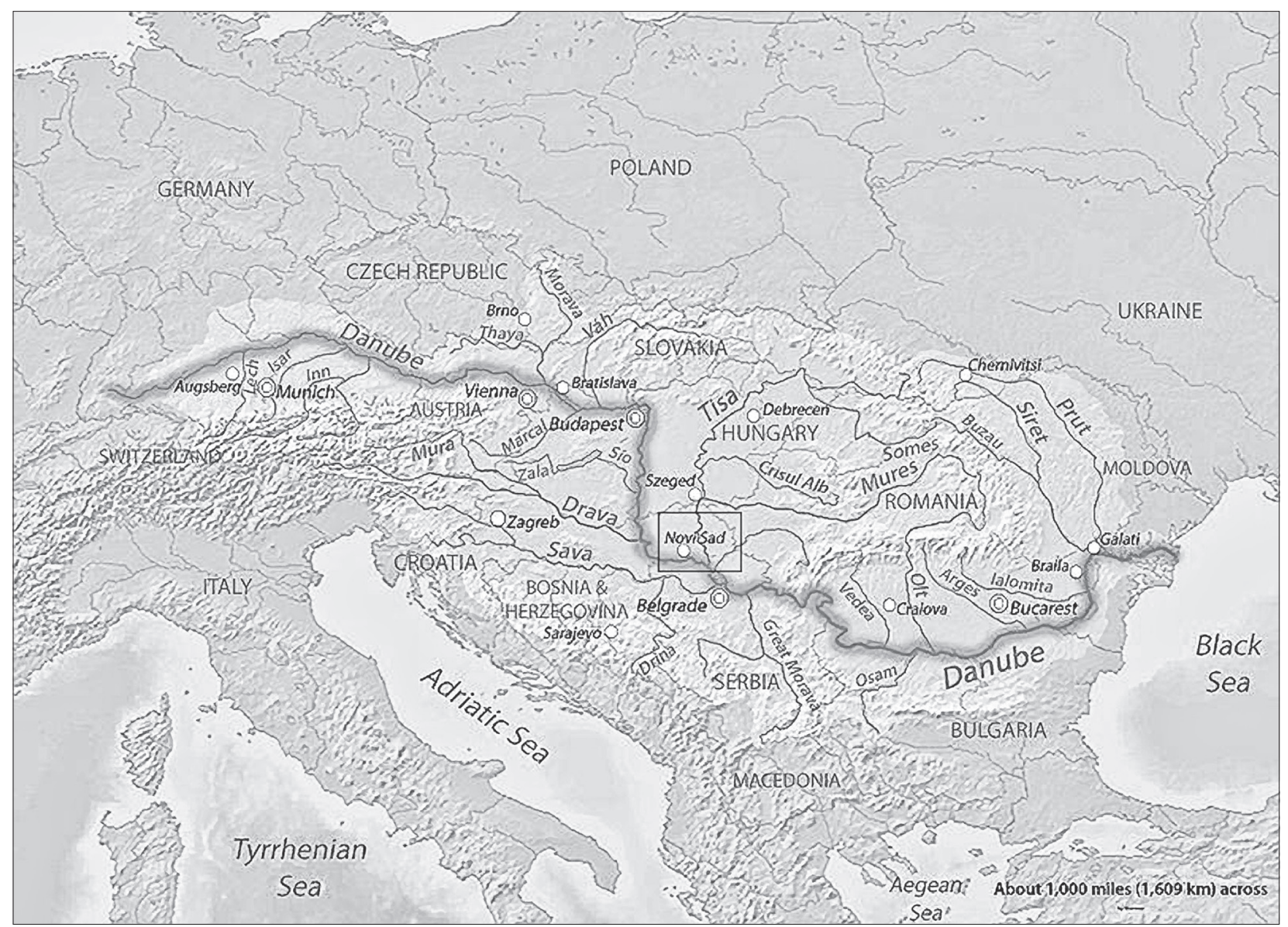

Figure 1: The Danube Basin

Source: http://www.danube-research.com/map.jpg 


\section{Research material and methods}

The present paper uses the data of the Republic Hydrometeorological Institute of Serbia for the period 2004-2011 (RHMI, 2004-2011). The results have been presented based on correlation analysis that was used to establish whether there is a corresponding intensity (level) of correlation and statistical significance between the dependent variables (parameters: $\mathrm{pH}, \mathrm{O}_{2}$ saturation, $\mathrm{BPK}_{5}$, suspended matters, total nitrogen oxides and coliform bacteria count) and independent variables (air temperature, water temperature and precipitation rate). The Pearson Correlation Test was applied to establish the variables with significant differences.

The correlation means the connection between variables while correlation coefficient means the measure based on which it can be concluded about the extent of their connection. The correlation coefficient indicates the extent up to which the changes in the value of one variable are accompanied by changes in the value of another variable (Turjačanin, Čekrlija, 2006). The correlation coefficient between two accidental variables $\boldsymbol{x}$ and $\boldsymbol{y}$, with the mean values $\bar{x}$ and $\bar{y}$ and standard deviations $\sigma_{x}$ and $\sigma_{y}$, is defined by means of the following formula:

$$
r_{x y}=\frac{\sigma_{x y}^{2}}{\sqrt{\sigma_{x x}^{2} \sigma_{y y}^{2}}}=\frac{\sum_{i=1}^{n}\left(x_{i}-\bar{x}\right)\left(y_{i}-\bar{y}\right)}{\sqrt{\sum_{i=1}^{n}\left(x_{i}-\bar{x}\right)^{2} \sum_{i=1}^{n}\left(y_{i}-\bar{y}\right)^{2}}}
$$

The correlation coefficient shows the rate of linear dependence between variables. If the values of $\boldsymbol{r}$ are closer to 1 or -1 the correlation between the analysed variables is higher. In the case that the value is equal to or it makes approximately zero, the variables are independent one from another, but the opposite case is not always exclusively true (namely, if two variables are mutually dependent their correlation coefficient can be o) because the correlation coefficient defines only the linear dependence between variables.

The square correlation coefficient $\left(\boldsymbol{r}^{2}\right)$, which is defined by identical formula that is squared, is used in the analysis of linear dependence between two variables:

$$
r_{x y}^{2}=\frac{\sigma_{x y}^{4}}{\sigma_{x x}^{2} \sigma_{y y}^{2}}=\frac{\left(\sum_{i=1}^{n}\left(x_{i}-\bar{x}\right)\left(y_{i}-\bar{y}\right)\right)^{2}}{\sum_{i=1}^{n}\left(x_{i}-\bar{x}\right)^{2} \sum_{i=1}^{n}\left(y_{i}-\bar{y}\right)^{2}}
$$

In this case, the value of $\boldsymbol{r}^{2}$ between two variables has to be positive in all cases (Wilks, 2006).

\section{Results fo correlation analysis}

When it comes to $\mathrm{pH}$ parameter, the values of coefficients indicate that there is the correlation between this parameter and air temperature parameter (Table 1). The results indicate a low connectedness ( $\mathrm{K}=0.257$; $\mathrm{r}=0.012$ ) between these two parameters, as well as a positive correlation symbol. Based on these indicators we can conclude that $\mathrm{pH}$ values decline if the air temperature is lower. The water temperature parameter, as the factor that could affect the increase or reduction in $\mathrm{pH}$ value, indicates also a low connectedness and relatively low correlation coefficient $(\mathrm{K}=-0.252 ; \mathrm{r}=0.014)$. As in previous cases, the correlation sign is positive and it points to the fact that $\mathrm{pH}$ values increase with the increase of water temperature. The total precipitation quantity does not affect significantly the changes in $\mathrm{pH}$ values of the Danube water near Novi Sad.

If we analyse the mutual connectedness between the $\mathrm{O}_{2}$ saturation percentage and air temperature we find that there is statistically significant connection between them. The correlation coefficient between the $\mathrm{O}_{2}$ saturation percentage and air and water temperature is low $(\mathrm{K}=0.247 ; \mathrm{r}=0.015)$, just as it is between the $\mathrm{O}_{2}$ saturation percentage and water temperature $(\mathrm{K}=0.265 ; \mathrm{r}=0.009)$. The correlation sign is positive, namely the $\mathrm{O}_{2}$ saturation percentage declines with the decline in air or water temperature. The correlation rates (Table 1 ) in total precipitation quantity are lower than 0.2 based on which we see that this natural factor does not affect changes in percentage of $\mathrm{O}_{2}$ saturation.

$\mathrm{BPK}_{5}$ is the parameter that also shows a low intensity correlation connection in relation to natural parameters (air and water temperature). The correlation rates (Table 1 ) are less than 0.4 and they have a positive signs for air temperature $(\mathrm{K}=0.317 ; \mathrm{r}=0.002)$ and water temperature $(\mathrm{K}=0.323 ; \mathrm{r}=0.002)$, based on which we conclude that these factors affects the reduction, namely increase in this parameter. The increase of biological oxygen consumption follows the increase in temperature. As with previous parameters, the precipitation quantity has no significant impact on changes in $\mathrm{BPK}_{5}$ in the Danube water near Novi Sad.

As far as suspended substances are concerned, we also find a low correlation connectedness in relation to air and water temperature (Table 1$)-(\mathrm{K}=0.242$; $\mathrm{r}=0.018)$ for air temperature and $(\mathrm{K}=0.240 ; \mathrm{r}=0.018)$ for water temperature. Low correlation level and positive correlation sign indicate a low impact whereby the quantity of suspended substances increases with the increase of temperature. The precipitation quantity has no significant impact on changes in suspended substances in the Danube water near Novi Sad. 
Table 1. Correlation analysis of impact of air and water temperature, and precipitation on certain chemical water parameters

\begin{tabular}{|c|c|c|c|c|c|c|c|}
\hline Parameter & & $\mathrm{pH}$ & $\mathrm{O}_{2}$ saturation & $\mathrm{BPK}_{5}$ & $\begin{array}{l}\text { Suspended } \\
\text { substances }\end{array}$ & $\begin{array}{l}\text { Total nitrogen } \\
\text { oxides }\end{array}$ & $\begin{array}{c}\text { Coliform } \\
\text { bacteria count }\end{array}$ \\
\hline \multirow{2}{*}{$\begin{array}{l}\text { Air } \\
\text { temperature }\end{array}$} & K & 0,257 & 0,247 & 0,317 & 0,242 & $-0,788$ & 0,291 \\
\hline & $P$ & $0,012^{*}$ & $0,015^{*}$ & $0,002^{*}$ & $0,018^{*}$ & $0,000 *$ & 0,213 \\
\hline \multirow{2}{*}{$\begin{array}{l}\text { Water } \\
\text { temperature }\end{array}$} & K & 0,252 & 0,265 & 0,323 & 0,240 & $-0,808$ & 0,230 \\
\hline & $P$ & $0,014^{*}$ & $0,009 *$ & $0,002^{*}$ & $0,018^{*}$ & $0,000 *$ & 0,330 \\
\hline \multirow{2}{*}{ Precipitation } & K & 0,009 & 0,030 & 0,071 & 0,005 & $-0,166$ & 0,339 \\
\hline & $P$ & 0,928 & 0,770 & 0,506 & 0,960 & 0,106 & 0,144 \\
\hline
\end{tabular}

Note: * $P<0.05 ; K$-correlation coefficient obtained based on the Pearson Correlation Test

When it comes to the parameter of total nitrogen oxides, the correlation coefficient points to the fact that there is a highly significant correlation between this parameter and air temperature (Table 1). The results indicate a high connectedness $(\mathrm{K}=0.788$; $\mathrm{r}=0.000$ ) between these two parameters, as well as a negative correlation sign. Based on these indicators we can conclude that the value of nitrogen oxide decreases if the air temperature rises. Water temperature, as the factor that could affect the increase or reduction of nitrogen oxide in water, also indicates a very high correlation level $(\mathrm{K}=-0.808 ; \mathrm{r}=0.000)$. As in the case of air temperature, the correlation sign is negative and it points to the fact that the values of total nitrogen rise if the water temperature decreases. The total precipitation quantity has no significant impact on changes in the values of nitrogen oxide in the Danube water near Novi Sad. Discharge of nitrogen contributes significantly to the pollution of the Danube in its downstream section. It is estimated that Serbia discharges annually around $14 \%$ of the total discharged quantity of nitrogen. These values place Serbia at the third position according to the quantity of discharged nitrogen among the Danube Basin countries. Nitrogenous substances cause eutrophication of watercourses and stimulate organic production (Camargo et all., 2005; Monette et all., 2006; Parr, Mason, 2003). Once the algae vegetation period passes, they will become the substrate for microorganisms and after they pass through the food chain, they will cause the occurrence of additional mud in the watercourse and oxygen consumption. The occurrence of toxic pollutants aggravates the above/mentioned negative processes (Turgut, 2003). Separated sludge and autochthonous mud in the watercourse becomes toxic itself due to depositing of toxic pollutants (Akcay et all., 2003).

The coliform bacteria count is the parameter that does not show significant correlation connectedness compared to natural factors (air temperature, water temperature, and precipitation quantity). The correlation levels (Table 1) do not show statistical significance.
Based on that we can conclude that natural factors do not affect the reduction, namely increase of this parameter.

\section{Conclusion}

Based on the results of the study that analysed the impact of natural factors on water quality of the river Danube near Novi Sad it has been established that natural factors, primarily air and water temperature affect changes in water quality throughout the year. The natural factors affect mostly the nitrogen oxide concentration whereby the concentration of this parameter increases with the decline in temperature. A sudden proliferation of algae appears in the conditions of high concentration of nitrogen in water and a large quantity of oxygen is consumed as the result of their dieing out for dissolving of organic matter. The lack of oxygen affects negatively the aerobic organisms in water, primarily fish.

Certain correlation with water and air temperature is also found in other water quality parameters, but such correlation is at a relatively low level. The increase of temperature results with the increase of $\mathrm{pH}$ value in water, increase of the $\mathrm{O}_{2}$ saturation percentage and increase in $\mathrm{BPK}_{5}$ concentration. Sedimenting of suspended substances, which is more intensive during the warmer period of the year is another problem. Suspended substances fill the river canal with sediments and these are the compounds for the oxidation of which microorganisms consumer oxygen. In this way, the species living in a watercourse and using oxygen are being threatened. Due to sedimentation two negative effects occur: the stockpiling of mud in a watercourse and ecological damage due to reducing of the concentration of dissolved oxygen below the biological minimum.

Precipitation does not affect water quality parameters throughout the year.

Although the anthropogenic impact on the quality of watercourses is far more intensive, this study has established that natural factors may affect the in- 
crease or reduction of concentration of polluted water throughout the year up to a certain extent.

\section{Acknowledgment}

The paper is a part of the Project No. 114-451-2446/2012 financed by the Provincial Secretariat for Science and Technological Development of the Autonomous Province of Vojvodina, Serbia.

\section{References}

Akcay, H., Oguz, A and Karapire, C., 2003. Study of heavy metal pollution and speciation in Buyak Menders and Gediz River sedimants. Water Research 37 (17), 4086-4094.

Bhaduri, B., Minner, M., Tatalovich, S., Harbor, J., 2001. Long-term hydrologic impact of urbanization: A table of two models. Journal of Water Resources Planning and Management 127 (1), 13-19.

Bordalo A. A., Nilsumranchit W. \& Chalermwat K., 2001. Water quality and uses of the Bangpakong River (Eastem Thailand). Water Research 35, 36353642.

Camargo, A.J., Alonso, A., Puente, M., 2005. Eutrophication downstream from small reservoirs in mountain rivers of Central Spain. Water Research 39 (14), 3376-3384.

Córdoba E. B., Martínez A. C., Ferrer E. V., 2010. Water quality indicators: Comparison of a probabilistic index and a general quality index. The case of the Confederación Hidrográfica del Júcar (Spain). Ecological Indicators 10 (5), 1049-1054.

Dalmacija, B., 2004. Analysis and innovation of the information subsystem water use. Faculty of Science, Department of Chemistry, Novi Sad.

Gavrilović, Lj., Dukić, D. 2002. Serbian Rivers. Institute for textbooks and teaching aids, Belgrade.

Herna'ndez-Romero, A. H., Tovilla-Herna'ndez, C., Malo, E. A., Bello-Mendoza, R., 2004. Water quality and presence of pesticides in a tropical coastal wetland in southern Mexico. Marine Pollution Bulletin 48, 1130-1141.
Milanović A., J. Kovačević-Majkić, i M. Milivojević. 2010. Analysis of water quality of the Danube in Serbia - the problems of pollution and protection. Bulletin of the Serbian Geographical Society 90, (2), 47-68.

Monette, F., Lasfar, S., Millette, L., Azzouz, A., 2006. Comprehensive modeling of mat density effect on duckweed (Lemna minor) growth under controlled eutrophication. Water Research 40 (15), 2901-2910.

Parr, L.B., Mason C.F., 2003. Long-term trends in water quality and their impact on macroinvertebrate assemblages in eutrophic lowland rivers. Water Research 37 (12), 2969-2979.

Ren, W., Zhong, Y., Meligrana, L., Anderson, B., Watt, W.E., Chen, J., Leung, H.L., 2003. Urbanization, land use, and water quality in Shanghai 1947-1996. Environment International 29 (5), 649-659.

RHMZ - Republic Hydrometeorological Service of Serbia (2004-2011). Annual Report - Water quality. Belgrade: Republic Hydrometeorological Service of Serbia.

Rudolf A., Ahumada, R., Pe'rez, C., 2002. Dissolved oxygen content as an index of water quality in San Vicente Bay, Chile (36 degrees, 450S). Environmental Monitoring and Assessment 78, 89-100.

Sa'nchez A., Colmenarejo F. M., Vicente J., Rubio A., Garci'a G. M., Travieso L., \& Borja R., 2007. Use of the water quality index and dissolved oxygen deficit as simple indicators of watersheds pollution. Ecological Indicators 7, 2, 315-328.

Shrestha, S., Kazama, F., 2007. Assessment of surface water quality usingmultivariate statistical techniques: A case study of the Fuji river basin, Japan. Environmental Modelling \& Software 22 (4), 464475.

Turgut, C., 2003. The contamintion with organochlorine pesticides and heavymetals in surface water in Kiiciik Menderes River in Turkey, 2000-2002. Environment International 29, 29-32.

Xian, G., Crane, M., Junshan, S., 2007. An analysis of urban development and its environmental impact on the Tampa Bay watershed. Journal of Environmental Management 85 (4), 965-976. 